\title{
CURRENT STATUS AND PROBLEMS OF VIETNAMESE AGRICULTURAL SECTOR
}

\author{
Huong Le Thi Mai \\ Ho Chi Minh University of Technology and Education, Ho Chi Minh City, Vietnam \\ Hung Tran Van \\ Vietnam National University of Forestry, Đong Nai, Vietnam
}

Basing on the secondary data collected from the General Statistics Office of Viet Nam, this article describes the actual situation in Vietnamese agricultural sector through the contribution of agriculture to the economic growth and GDP of Vietnam, the export value of agricultural sector in the total export value of Vietnam, labor productivity of the agricultural sector and investments in the agricultural sector. Beside many achievements, the agricultural sector is currently facing a lot of challenging issues: (a) labor productivity is still low; (b) the use of funds is inefficient although capital investment in agriculture increased rapidly over the years; (c) the growth rate of agricultural sector is still low due to small-scale production; (e) disease issues, sanitary and phytosanitary safety; $(f)$ food safety, ( $g$ ) environmental pollution from cultivation and livestock farming have not been strictly controlled. Stemming from all these facts, this article proposes some recommendations which can contribute to overcoming the problems and developing the agricultural sector in the future.

Keywords: agricultural sector; safety issues; Vietnam.

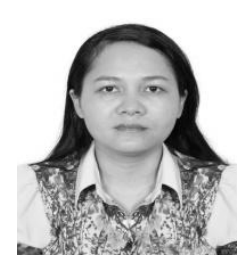

\section{Huong Le Thi Mai}

$\mathrm{PhD}$ (The technological current status of Vietnamese enterprises with the requirements of international integration)

Lecturer in Finance, University of Finance and Marketing, Ho Chi Minh, Vietnam

Science interests -financial sector, banking sector, SMEs functioning and government support, ecological economics, environmental issues of economic development and corporate social responsibility.

E-mail: : maihuongbd@gmail.com

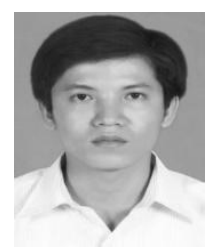

\section{Hung Tran Van}

$\mathrm{PhD}$ (The technological current status of Vietnamese enterprises with the requirements of international integration)

Lecturer Faculty of Economics, Vietnam National University of Forestry, Southern Campus, Dong Nai Province, Vietnam

Research interests - markets of agricultural products, SMEs functioning and government support, ecological economics, environmental issues of economic development and corporate social responsibility, financial management. Published more than 20 papers in International journals, member of editorial board of International journals.

E-mail: tranhungln2@gmail.com 


\section{CURRENT STATUS AND PROBLEMS}

\section{Introduction}

Since the implementation of a comprehensive renovation policy economy (1986), Vietnam's agriculture has made great achievements, confirming the important role of strategies in the development process of the country. Even during the phases of economic uncertainty, Vietnam has maintained high growth rates and long-term stability by changing the structure of plant cultivation and animal farming in a positive direction (Binh, 2017). Farming, livestock, forestry and fisheries, all have reached significant levels of development with diversity in both product types and organizational structure. Production systems of medium and large scales have been formed, notably in livestock farming, rice cultivation, aquaculture and perennial crops.

In 2017 the agricultural sector contributed $15.34 \%$ of GDP and $22.57 \%$ of the export value (Calculating from General statistics). Although being affected by economic downturn, the agricultural sector was the only sector that has export surplus during 2010-2017. In 2017, the export value of agriculture - forestry - fishery sector in the country reached 30.86 bln USD, increasing by $11.2 \%$ as compared to 2016; therefore, it continues to be the sector that creates high added value with over 9.5 bln USD (Calculating from General Statistics).

According to the data published by the General Department of Vietnam Customs, the agricultural sector has 10 commodity lines with more than 1 bln USD of the total turnovers, including: rice, coffee, rubber, cashew, pepper, cassava, vegetables, shrimp, fish and forestry products. While other industries are heavily influenced by the economic slowdown, the agricultural sector has overcome many difficulties, achieving a comprehensive and high growth rate. However, besides the achievements, Vietnamese agricultural sector still demonstrates some restrictions and weaknesses.

Therefore, assessment of the actual situation and detecting the most acute problems of this sector necessary.

\section{Methodology of the research}

\section{Objectives of the research}

This research has analyzed the actual situation and challenges of Vietnamese agricultural sector.

\section{Methods of data collection}

The article uses secondary sources of data which is collected from the General Statistics Office for further analysis and evaluation. They are specific data sources on the growth rate of the agricultural sector, contribution of agricultural sector to economic growth and GDP of Vietnam, value structure, namely agricultural farming, livestock and services agriculture, exports of the agricultural sector, export structure of farming, livestock and services in the export value of Vietnam's agricultural sector, employment structure, value structure and labor productivity in agriculture, investment in agricultural development, and efficient use of capital. 


\section{Results and Discussion}

\section{Contribution of agriculture to economic growth and Vietnam's GDP}

During the 1986-1990 Vietnam had the average economic growth rate of $4.4 \%$, in which the growth rate of the industrial sector was $7.4 \%$, services -- $8.3 \%$ and agriculture -$3.8 \%$. This was the stage to receive the achievements from innovations in economic thinking, opening of the economy for external investment flows etc. In the period of 1996-2000, agricultural sector had only $6.94 \%$ growth already and contributed $25.7 \%$ to GDP. The growth rate of the agricultural sector in the period of 2005-2017 tended to decrease and the share of its contribution to GDP was between 15.34 and 21\% (Calculations from General Statistics).

Table 1 - Contribution of agricultural sector to Vietnam economic growth and GDP, 1986 to 2017

(Source: GSO and calculations by the authors)

\begin{tabular}{|c|l|c|c|c|c|}
\hline No. & \multicolumn{1}{|c|}{ Target } & $\mathbf{1 9 8 6 - 1 9 9 0}$ & $\mathbf{1 9 9 1 - 1 9 9 5}$ & $\mathbf{1 9 9 6 - 2 0 0 0}$ & $\mathbf{2 0 0 1 - 2 0 0 5}$ \\
\hline $\mathbf{1 .}$ & $\begin{array}{l}\text { Growth rate of overall } \\
\text { GDP (\%) }\end{array}$ & $\mathbf{4 . 4}$ & $\mathbf{8 . 1 8}$ & $\mathbf{6 . 9 4}$ & $\mathbf{7 . 5 1}$ \\
\hline 1.1 & Industrial sectors & 7.4 & 12 & 10.6 & 10.25 \\
\hline 1.2 & Service sectors & 8.3 & 8.6 & 5.75 & 6.96 \\
\hline 1.3 & Agriculture sectors & 3.8 & 4.09 & 4.3 & 3.83 \\
\hline $\mathbf{2 .}$ & The structure of GDP (\%) & $\mathbf{1 0 0}$ & $\mathbf{1 0 0}$ & $\mathbf{1 0 0}$ & $\mathbf{1 0 0}$ \\
\hline 2.1 & Industrial sectors & 23.21 & 28.06 & 33.49 & 38.9 \\
\hline 2.2 & Service sectors & 41.15 & 41.77 & 40.81 & 39.45 \\
\hline 2.3 & Agriculture sectors & 35.64 & 30.16 & 25.7 & 21.66 \\
\hline No. & \multicolumn{1}{|c|}{ Target } & $\mathbf{2 0 0 6 - 2 0 1 0}$ & $\mathbf{2 0 1 1 - 2 0 1 5}$ & $\mathbf{2 0 1 6}$ & $\mathbf{2 0 1 7}$ \\
\hline $\mathbf{1 .}$ & $\begin{array}{l}\text { Grow rate of overall GDP } \\
\text { (\%) }\end{array}$ & $\mathbf{7 . 0 2}$ & $\mathbf{5 . 9 1}$ & $\mathbf{6 . 2 1}$ & $\mathbf{6 . 8 1}$ \\
\hline 1.1 & Industrial sectors & 7.94 & 7.22 & 7.57 & 8.02 \\
\hline 1.2 & Service sectors & 7.73 & 6.67 & 6.98 & 7.44 \\
\hline 1.3 & Agriculture sectors & 3.34 & 3.08 & 1.36 & 2.9 \\
\hline $\mathbf{2 .}$ & The structure of GDP $(\boldsymbol{\%})$ & $\mathbf{1 0 0}$ & $\mathbf{1 0 0}$ & $\mathbf{1 0 0}$ & $\mathbf{1 0 0}$ \\
\hline 2.1 & Industrial sectors & 37.89 & 33.13 & 32.71 & 33.4 \\
\hline 2.2 & Service sectors & 42.9 & 48.71 & 50.97 & 51.26 \\
\hline 2.3 & Agriculture sectors & 19.21 & 18.16 & 16.32 & 15.34 \\
\hline
\end{tabular}

In the period of 2005-2017, the growth rate of the agricultural sector was not high and lacked stability and sustainability. The agricultural growth rate reached $4.19 \%$ in 2005 then fell in 2006, 2007 and then rose to peak in 2008 (reaching 4.69\%) before dropping sharply to $1.91 \%$ in 2009. It then recovered in 2010 and 2011 but then sharply declined in 2012 and 2013 and raise up to $2.9 \%$ growth in 2017. 


\section{CURRENT STATUS AND PROBLEMS}

The restructuring of three production sectors - crops, breed, and services - over the period of 1986-2017 is demonstrated in Fig. 1.

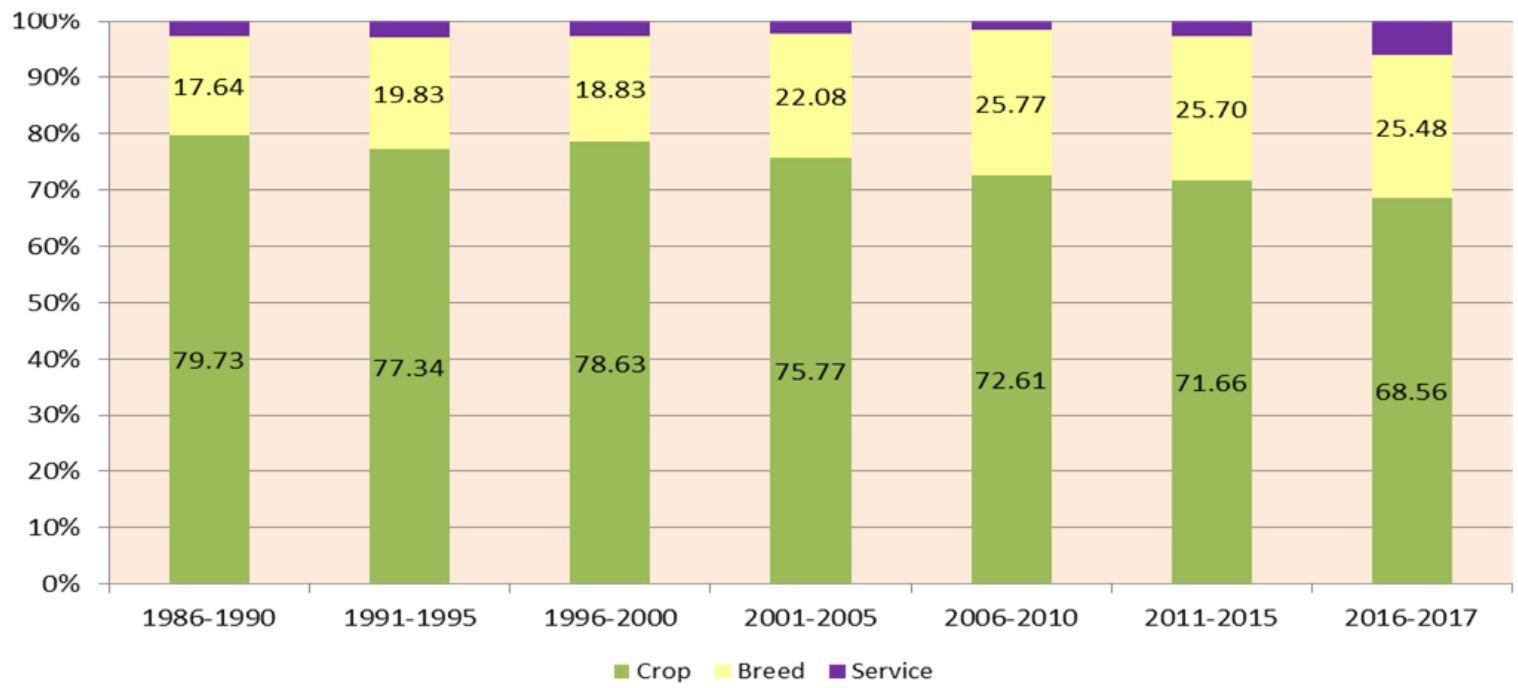

Figure 1 - Changing structure of Vietnamese agriculture, 1986 to 2017 (at current prices)

(Source: GSO and calculations by the authors)

In the value structure of the agricultural sector, farming still accounts for a large proportion, maintaining over $70 \%$ but it also demonstrates the tendency to decrease -- from $79.71 \%$ down to $71.96 \%$ during 1986-1990. Contrary to that, the livestock subsector tends to increase over the same period -- from $17.67 \%$ to $26.20 \%$. This indicates that the livestock industry is enhancing its value contribution to the agricultural sector overall. In addition, the share of agricultural services tends to increase but rather slowly and not that significantly.

\section{The value of agricultural exports in the total volume of Vietnam's exports}

Agriculture not only fulfills the requirement of national food security and domestic consumption but also meets the needs of agricultural production export which is concentrated around traditional Vietnamese brand products, such as rice, coffee, rubber, seafood. All of these products are major sources of foreign currency inflow to the country. In 1986, the value of agricultural, forestry and fisheries exports was around $486.2 \mathrm{mln}$ USD; however, in 2000 it already amounted to 4.2 bln USD and then even went beyond the threshold of 36.37 bln USD by 2017, which was almost 60 times higher than back in 1986.

Statistics about the export value of Vietnam's agriculture during the 1986-2017 period (Fig. 2) shows that the sector's share accounted for 54.01\% between 1986-1990, then there was a downward trend in the exports' structure which accounted for only $14.4 \%$ of the country in the period of 2016-2017. Despite the rise of the sector's export value, the share of the export value in the country tends to decrease. 


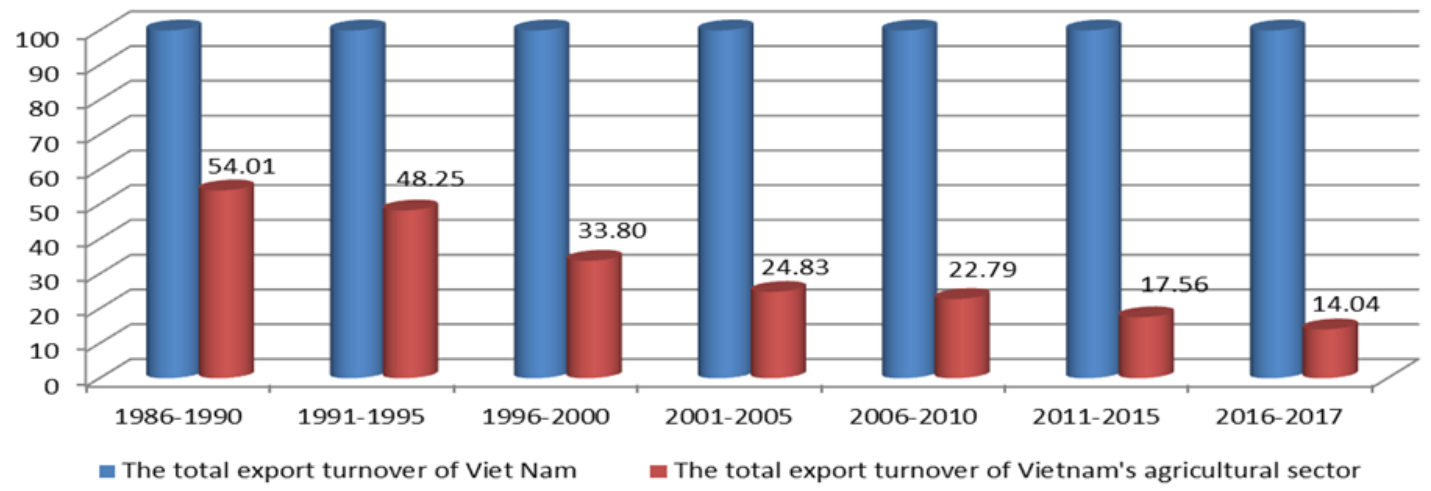

Figure 2 - The share of exports in the total agricultural export value of Vietnam in the period of 1986-2017 (in \%)

(Source: GSO and Calculations by the authors)

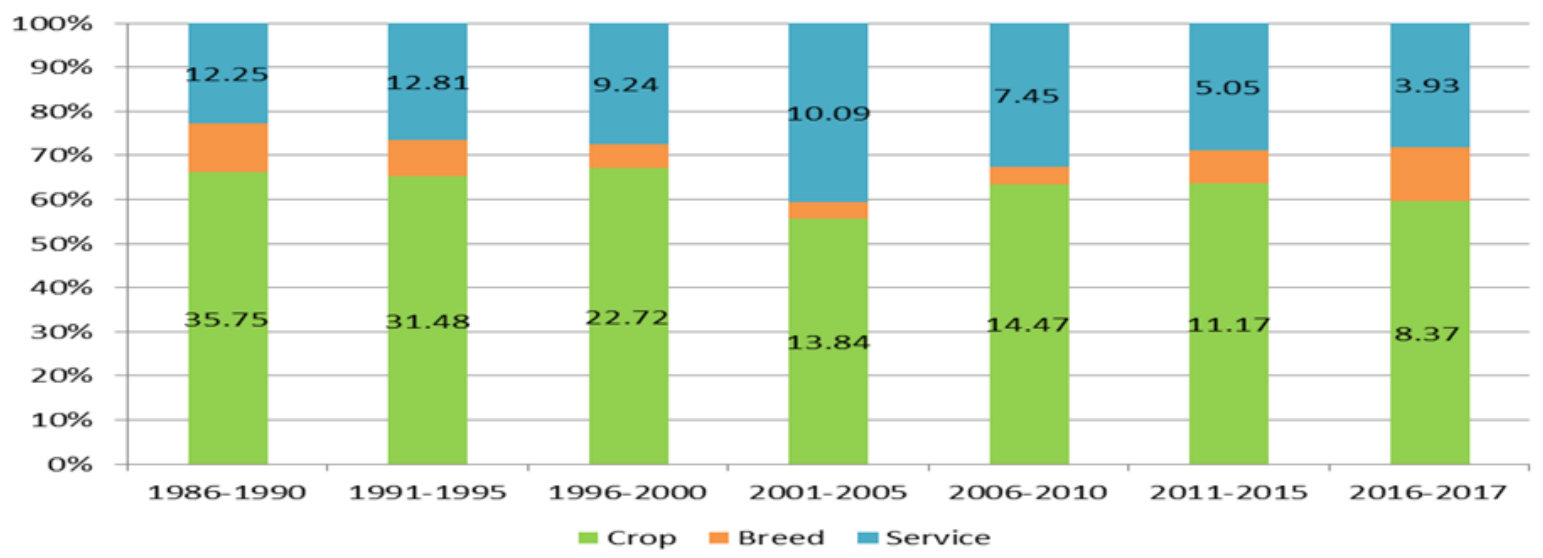

Figure 3 - The structure of exports in the value of agricultural exports Vietnam, 1986-2017 (in \%)

(Source: GSO and Calculations by the authors)

The growth rate of export turnover in agro-forestry reached the average of $17.31 \%$ per year over the period of 1986-2017. Particularly in 2017, the total export value reached 36.37 bln USD nationwide, which was $11.2 \%$ up as compared to 2016 . There were 10 items turnover of 1 bln USD (rice, coffee, rubber, cashew, pepper, cassava, vegetables, shrimp, fish, and forest products) in agriculture. Thanks to great achievements in exporting, agriculture is the only sector which always has a trade surplus, while Vietnam's overall trade is experiencing deficit on a regular basis. Export of agricultural products not only balances the national trade but also strengthens the position of Vietnam on the international arena.

We can see that the proportion of the value of agricultural exports still plays the key role, although exports have decreased over the years but remain to be at around $65 \%$. By 2013, Vietnam was ranked first in pepper export (accounting for 14.3\% of the world market), first in coffee export (40\% of the world market), second in rice export (12\% market share), 


\section{CURRENT STATUS AND PROBLEMS}

finally, the second in cashew export (accounting for 9.5\% of the world market). Contribution of the fisheries sector in the volume of agricultural exports has grown rapidly over time and accounted for the export volume worth $25-30 \%$ of the total export value, the main products being frozen shrimp and catfish.

\section{Industrial labor structure and labor productivity in agriculture}

In 1986, the agricultural sector attracted $72.91 \%$ of all workers in Vietnamese society (see Fig. 4). Vietnamese laborers tend to gradually shift to service industries because these latter industries have higher labor productivity as compared to agriculture, besides, working conditions are usually better in services. Thus, till 2017, the share of active labor in the agricultural sector fell down to $40.16 \%$.

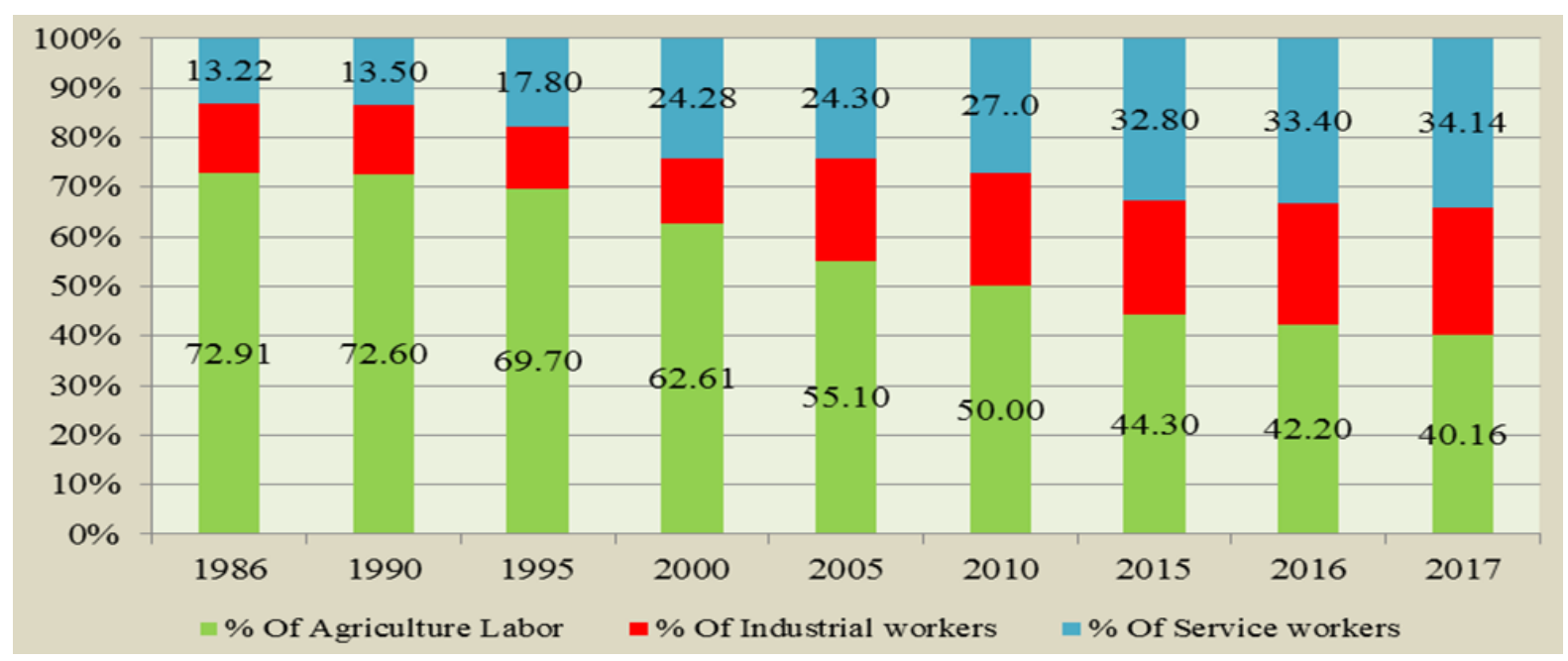

Figure 4 - Structure of the labor sector, 1986 to 2017 (in \%)

(Source: GSO and calculations by the authors)

Although labor in the agricultural sector accounted for the largest proportion of total national employment (46.3\% as of 2017), labor productivity of this sector was at very low levels (Tab. 2). Labour productivity in agriculture was estimated to be only $1 / 4.5$ of that of the industry and about $1 / 3.4$ of the service sector productivity.

Low yields indicated that the effect from the use of labor is low and the application of scientific achievements and advanced technologies is still limited. In 2017, labor productivity of Vietnam (calculated at current prices) reached $35.6 \mathrm{mln}$ VND per person, this was 1.08 times higher than in 2016. Employment in the agricultural sector accounted for the highest proportion in 2017 (40.16\%) but the value contribution to GDP accounted for only $18.12 \%$.

Social labor productivity in 2017 at current prices of the whole economy was estimated at $93.2 \mathrm{mln}$ VND / employees (equivalent to about 3,515 USD per laborer), in which labor productivity of agriculture, forestry and fisheries reached $35.6 \mathrm{mln}$ VND / employees, accounting for $38.9 \%$ of labor productivity of the whole economy; industrial sectors and construction reached $155.1 \mathrm{mln}$ VND which is higher by 1.8 times as compared to social labor productivity while services sector reached $120.9 \mathrm{mln} \mathrm{VND} /$ labor (1.36 times higher).

Calculated at constant prices of 2010, labor productivity across the economy in 2017 is estimated to be up $9.13 \%$ as compared to 2016 , while labor productivity of agriculture, 
forestry and fisheries increased by $8.2 \%$; productivity in industries and construction increased by $13.8 \%$; and in services sector - by $7.8 \%$.

Table 2 - Structure of labor, value structure and labor productivity in agriculture of Vietnam, 1986 to 2017

(Source: GSO and calculations by the authors)

\begin{tabular}{|c|c|c|c|c|c|c|c|c|c|c|}
\hline \multirow{2}{*}{ Year } & \multicolumn{3}{|c|}{$\begin{array}{c}\text { Labor structure of economic } \\
\text { sectors (\%) }\end{array}$} & \multicolumn{3}{c|}{$\begin{array}{c}\text { Contribution to GDP at } \\
\text { current prices }(\%)\end{array}$} & \multicolumn{3}{c|}{ Labor productivity at current prices (mln } \\
\cline { 2 - 12 } & Agri & Industry & Service & Agri & Industry & Service & $\begin{array}{c}\text { Whole } \\
\text { economy }\end{array}$ & Agri & Industry & Service \\
\hline 1986 & 72.91 & 13.87 & 13.22 & 38.06 & 28.88 & 33.06 & 2.43 & 1.26 & 5.04 & 6.06 \\
\hline 1990 & 72.6 & 13.9 & 13.5 & 38.66 & 22.7 & 38.64 & 15.67 & 6.54 & 28.29 & 24.94 \\
\hline 1995 & 69.7 & 12.5 & 17.8 & 27.18 & 28.76 & 44.06 & 16.86 & 6.82 & 31.48 & 26.73 \\
\hline 2000 & 62.61 & 13.1 & 24.28 & 24.54 & 36.73 & 38.73 & 18.23 & 7.09 & 35.26 & 29.03 \\
\hline 2005 & 55.1 & 20.6 & 24.3 & 21.58 & 38.12 & 40.31 & 19.5 & 7.4 & 39 & 30.7 \\
\hline 2010 & 49.5 & 21 & 29.5 & 18.89 & 38.23 & 42.88 & 44 & 16.8 & 80.3 & 63.8 \\
\hline 2011 & 48.4 & 21.3 & 30.3 & 18.5 & 38.39 & 43.12 & 55.2 & 22.9 & 98.3 & 76.5 \\
\hline 2012 & 47.4 & 21 & 31.6 & 18.05 & 38.57 & 43.38 & 63.1 & 26.2 & 115 & 83.7 \\
\hline 2013 & 46.8 & 21 & 32.2 & 17.57 & 38.57 & 43.86 & 68.7 & 27 & 124.1 & 92.9 \\
\hline 2014 & 46.6 & 21.4 & 32 & 18.12 & 38.5 & 43.38 & 74.3 & 28.9 & 133.4 & 100.7 \\
\hline 2015 & 44.3 & 22.9 & 32.8 & 17.00 & 33.15 & 49.75 & 79.4 & 30.6 & 133.6 & 106.6 \\
\hline 2016 & 42.2 & 24.4 & 33.4 & 16.32 & 32.72 & 50.96 & 84.5 & 32.9 & 136.2 & 112.1 \\
\hline 2017 & 40.16 & 25.7 & 34.1 & 15.34 & 33.40 & 51.26 & 93.2 & 35.6 & 155.1 & 120.9 \\
\hline
\end{tabular}

In general, labor productivity in agriculture is the lowest labor productivity of the whole economy and also the lowest among all employees working in all the sectors of the economy. Besides, growth rate of agricultural productivity is also very low, and this fact makes agricultural workers to be lagging behind all other workers within Vietnamese economy.

\section{Investment capital for development of agricultural sector}

Social investment capital for Vietnamese agricultural sector increased by 2.3 times, from 9 trln VND back in 1995 to over 20 trln in 2007. But the growth rate is very low, as compared to investments in the social services sector (increased by 4,4 times) and industry (6.2 times increase). Of the total investment during the ten years (2001-2010, calculated at current prices) which was above 4336.6 trln VND, investments in agriculture, forestry and fisheries were at the level of 304.8 trln, accounting for 7\%; industrial sectors and construction got 1792.9 trln, accounting for $41.4 \%$; services -- $2238.9 \operatorname{trln}$, accounting for 51.6\%. In 2000, total investments in agriculture accounted for about $13.8 \%$ of GDP. Afterwards, there was a range of falls: by $7.5 \%$ in 2005 , by $6.45 \%$ in 2008 and by $6.26 \%$ in 2010. However, in 2017, although the investment was 61.2 trln VND already, thus increasing by almost 3 times as compared to 2000, the proportion of capital allocated to the sector fell 


\section{CURRENT STATUS AND PROBLEMS}

by $5.6 \%$. Thus, agricultural investments, as we can see, can not be commensurated with the potential development of the industry. New capacities in infrastructure have not been formed and are still required for the restructuring of the agricultural sector according to its current development objectives. Investments in high-quality agriculture, planting and animal breeding, post-harvest technologies' development are urgently required.

All these factors made agricultural products be the products of low added value, with hardly any impetus to agricultural development. Meanwhile, the proportion of investments in industries and especially services tends to expands, it accounted for 58.3\% in 2017 alone.

Table 3 - Investment volumes by the sectors of Vietnamese economy, 2000 to 2017 (Source: GSO and calculations by the authors)

\begin{tabular}{|c|c|c|c|c|c|}
\hline \multirow{2}{*}{ Year } & \multicolumn{2}{|c|}{$\begin{array}{c}\text { Total investments (thousand } \\
\text { billions dong) }\end{array}$} & \multicolumn{3}{|c|}{ The proportion of capital allocated to the } \\
\cline { 2 - 6 } & $\begin{array}{c}\text { Economy } \\
\text { overall }\end{array}$ & $\begin{array}{c}\text { Investments in } \\
\text { agriculture }\end{array}$ & Agriculture & Industry & Services \\
\hline 2000 & 151.2 & 20.9 & 13.8 & 39.2 & 47 \\
\hline 2005 & 343.1 & 25.7 & 7.5 & 42.6 & 49.9 \\
\hline 2010 & 830.3 & 54 & 6.5 & 40.5 & 53 \\
\hline 2011 & 924.5 & 55.3 & 6 & 40.4 & 53.6 \\
\hline 2012 & $1,010.10$ & 52.9 & 5.2 & 41.5 & 53.3 \\
\hline 2013 & $1,094.50$ & 61.2 & 5.6 & 41.8 & 52.6 \\
\hline 2014 & $1,220.7$ & 61.5 & 5.3 & 42.4 & 52.3 \\
\hline 2015 & $1,336.5$ & 76.5 & 5.6 & 38.0 & 56.4 \\
\hline 2016 & $1,487,6$ & 87.5 & 5.9 & 37.5 & 56.6 \\
\hline 2017 & $1,668,6$ & 100.1 & 6.0 & 35.7 & 58.3 \\
\hline
\end{tabular}

In addition, although investments in the agricultural sector increased rapidly over the years and the average increase was over $10 \%$ in the period from 2000 to 2017, still, agriculture's ICOR in the period from 2000 to 2017 increased from 2.09 in 2000 to 6.4 in 2009 and then fell to 4.49 in 2017, thus reflecting the efficient use of capital in the agricultural sector has declined recently. In the period of 2000-2005, the average ICOR was at 2.1 to 1 ; it means that Vietnam needs to invest 2.1 capitals to get 1 capital of agricultural growth. During the period from 2006 to 2010, there was an average increase of ICOR to 3.8, and then there was 3.5 in the period of 2011-2013. 


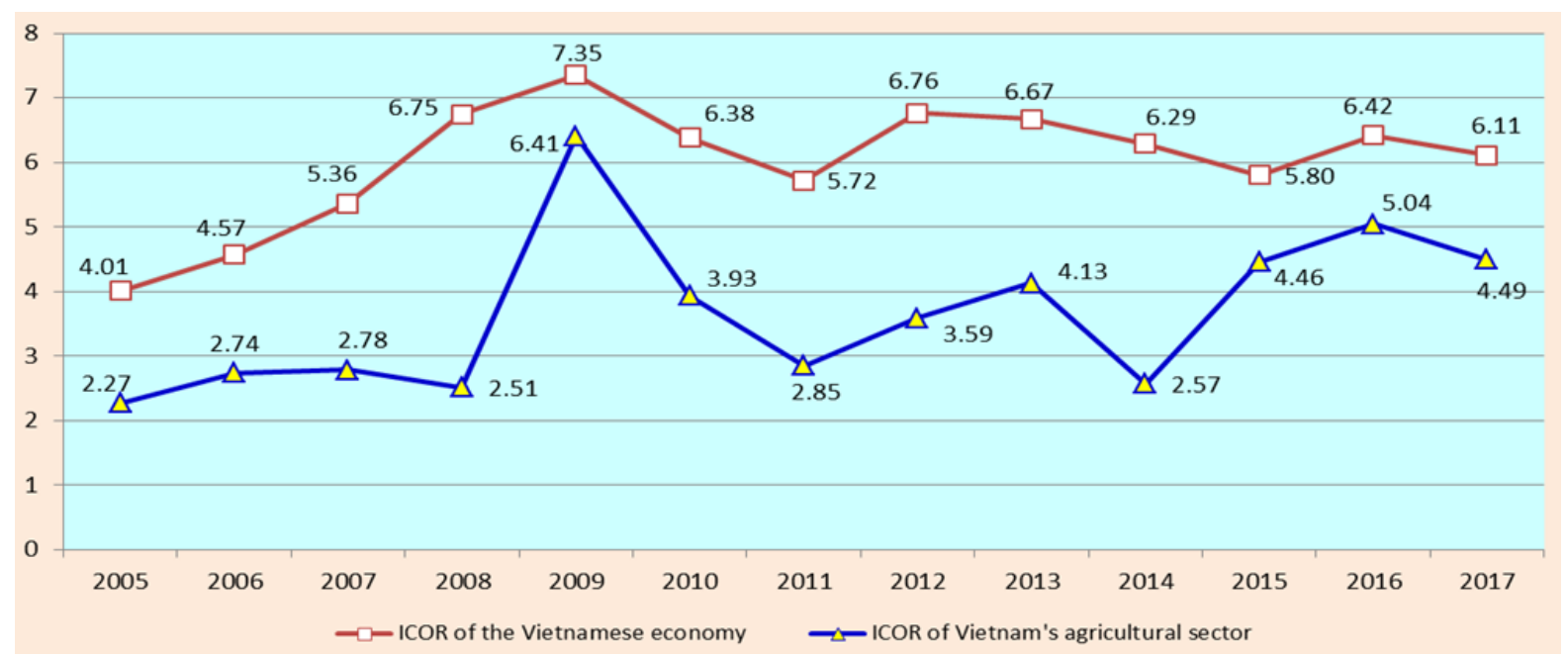

Figure 5 - ICOR of Vietnamese economy and agriculture during 2000-2017

(Source: GSO and calculations by the authors)

From the analysis on the current situation it can be seen that agricultural sector has made remarkable achievements, thus contributing to the overall development of the country. However, the sector has also been facing many problems affecting its development. They are discussed in the next sections.

\section{The problems of Vietnamese agricultural sector}

First of all, labor productivity in agriculture is still very low. Labor in the agricultural sector accounts for the largest proportion as compared to other sectors of Vietnamese economy. However, labor productivity of this sector is very low and is estimated to be only $1 / 4.5$ to that of industries and about $1 / 3.4$ to that of the service sector productivity.

Secondly, investment in the agricultural sector increased rapidly over the years and the average increase has been over $10 \%$ in the period from 2000 to 2017 . However, efficiency of this investment is not that high as it is expressed through ICOR in agriculture falling from 6.41 in 2009 to 4.49 in 2017.

Thirdly, after joining the WTO in 2007 and signing free trade agreements (FTAs) with several countries, the general trend of growth rate of the agricultural sector in the 2005-2014 period is very low, less than $3 \%$ per year. We have reasons to believe that in the situation of ongoing strengthening of the integration trends, the agricultural sector of Vietnam will continue to face many previous and new difficulties. The level of competition with imported products is increasing intensively, especially when it comes to competition within the ASEAN region after the ASEAN Economic Community (AEC) was established at the end of 2015. By the end of 2014, the level of trade liberalization in the ASEAN region was the highest with approximately $75 \%$ of all import tariffs being reduced to $0 \%$. Joining the AEC requires faster and broader tariffs' reduction. Therefore, only most sensitive agricultural commodities remain to be taxed at the rate of $5 \%$ only, while the meat import tax, for example, will be soon reduced to $0 \%$. This is a significant challenge to Vietnamese agricultural sector. In addition, the growth rate of the agricultural sector in Vietnam has decreased due to negative impacts of the world market prices for materials and products 


\section{CURRENT STATUS AND PROBLEMS}

(supply price increases, while agricultural prices do not increase or even decrease, thus creating unfavorable terms of trade for agricultural producers) and the increase of trade barriers related to food safety of the agricultural commodities exported from Vietnam.

Fourth, agricultural production is still mostly small in size and dispersed. It is also heavily dependent on imported input factors such as seeds, fertilizers, pesticides, veterinary drugs, animal feed and so on. High input costs can be also explained by this serious dependence on imported input materials for manufacturing and farming. This leads to agricultural production in Vietnam being very costly in general. Besides, post-harvest preservation and processing technologies are still not that widely spread in the country, so the added value of agricultural products is not high and there are not many key products with recognizable national brands.

Fifth, output markets for Vietnamese agriculture are also experiencing lack of investment and underdevelopment. Competitive capacity of the agricultural sector is low because of low productivity and low quality of agricultural products. The consumption markets are unstable, not enough diverse and strongly dependent on a few traditional markets. The main export channel is direct export through unofficial channels which leads to many potential risks.

Sixth, tax reduction due to joining AFTA, TPP, EAC and other associations will lead to rapid increase of product import from the neighbouring countries with well developed industrial production. The products from these countries have formidable competitive advantage as compared to Vietnamese products. Therefore, agricultural products from other ASEAN countries, China, South Korea etc. will soon enter Vietnam with their cheap prices, high quality and wide varieties of design. Agricultural products, businesses and farmers in Vietnam will be facing stiff competition, and this inevitable means farmers become the most vulnerable subjects during the ongoing integration period.

Seventh, there are also serious issues related to diseases, sanitary and phytosanitary safety, food safety, and environmental pollution. All of these issues in livestock farming and cultivation have not been controlled yet. If there will be no sufficient barriers with effective sanitary and phytosanitary measurement, Vietnam will become a consuming market for lowquality products only. This will affect the health of consumers and cannot protect domestic producers. Meanwhile, the present regulations about waste water management in livestock farming are making difficulties for business. In Thailand and other countries (more developed as compared to Vietnam) composting and waste waters only need to be incubated and filtered through biogas systems prior to be used for plant irrigation while Vietnam requires wastewater treatment to meet Class $\mathrm{A}$, thus leading to higher costs of production for livestock enterprises.

Eighth, research and application of science and technologies in agricultural production as well as investment in science and technologies in the field of agriculture are still rather limited. In the context of economic integration, comprehensive quality enhancement of agricultural production is facing numerous challenges. Investment in high-tech, clean agriculture and development of genetic technology requires high capital costs which would be needed in a long term while agriculture still demonstrates low efficiency and slow payback. 


\section{Conclusions And Recommendations}

Vietnam's economy has been evolving from the status of a backward agricultural country as it was gradually reviving after the war. During these 30 years of innovations in the field of agriculture, the policies of the Party and the State set the priorities in the development of agriculture through policy reforms, namely in: agricultural policy, land policy for agriculture, deposit and capital investment policy in agriculture, and policies of science and technology. Development of these policies and implementation of the reforms together have pushed Vietnamese agricultural sector through the stage of import dependence to self-sufficiency in food first and then -- to the stage of becoming a food-exporting country. As of today, Vietnam has ten most exported agricultural products which have the value over a billion dollars each. Thus, even in the period of economic slowdown, the agricultural sector remains to demonstrate stable growth.

Despite many achievements, the agriculture of Vietnam still faces many challenges. Agricultural products are less competitive as compared to other countries in the region and the world overall. There are not many high value-added agricultural products in the country. Agricultural productions are mostly small and fragmented. Although capital investment in the sector has increased over the years but it still can not commensurate with the potential of the agriculture. Labor productivity of the sector is still low, so the lives of workers have not much improved. Epidemics and environmental pollution in livestock farming are not strictly controlled, thus causing additional problems. To support sustainable development of the agricultural sector in the coming period, the government should develop more efficient investment policies, so that the sector can develop commensurately with its advantages and already available capabilities. Therefore, in the coming period, Vietnam should focus on implementing a number of key issues as follows:

Support for product sales and market development: The domestic market needs to be restructured. The wholesale and retail systems need to be developed with more emphasis on market development in remote and minor ethnic areas so that to encourage the development of social enterprises and ensure more benefits for direct producers. For export, traditional markets should be maintained and new markets should be entered focusing on building product brand names, improving product quality, reducing costs. Together all this would increase the external competitiveness. Investigations, surveys and other forms of market research on agricultural, forestry and aquatic products need to be done to capture consumer preferences, changing product structure, pricing, and trading practices at different markets. A team of experts capable of analysis, research, and market forecasts need to be established to give advise and propose effective policies to the government. The role of industrial associations in providing relevant information and in implementation of the development strategy for production, business collaboration, negotiating and signing contracts needs to be strengthened.

Improving the efficiency of capital use: Financial sources need to be diversified to keep up growing investment in development of economic infrastructure and rural society. There must be special policies developed for the enterprises that would like to participate in businesses affiliate to farmers. They must be able to get mid-term and long-term loans under preferential interest rates when they are implementing this affiliated business model. A separate fund should be established to support farmers in production and post-harvest technology (first and foremost - for rice products) since extra research is needed to raise 


\section{CURRENT STATUS AND PROBLEMS}

production yield and reduce post-harvest losses. All investment funds, current and future, should be used for the right objectives, right purpose and be aimed at reaching higher effectiveness in the first place.

Scientific and technological applications: Research and application of scientific achievements and advanced technologies must be promoted more actively. This is especially relevant for the transfer of scientific and technological achievement aimed to improve quality of seeds and livestock, with the ability to prevent and overcome diseases among plants and animals etc. More active application of biotechnologies and construction of high-tech agricultural zones are also essential in this regard. Encouragement and establishment of favorable conditions for enterprises and cooperative organizations need to be developed to invest in preservation and processing of agricultural, forestrial, and seafood products.

Training and development of human resources: There must be special conditions introduced along with special remuneration policies so that to attract scientists from the field of high technologies to work in agricultural sector. Of special importance would be to encourage young highly qualified staff to work in rural areas. Training and retraining of staff working on building a new countryside also need to be in the focus of governmental attention. Vocational trainings for rural workers need to be organized so that they get more capable of planning, restructuring and economic development taking into account the specific conditions of their own localities.

Quality of vocational training overall needs to be improved, especially in the most remote areas, mountainous areas and areas with socioeconomic difficulties.

Development models: New models and forms of efficient production organization in rural areas need to be developed and implemented. Closed production chains that involve only local stakeholders need to be promoted. Policies are needed to encourage collaborations between farmers and businesses, cooperatives, scientific organizations, industrial associations and product consuming markets in order to support the development of both family farms and large-scale commodity production. There is also a need to establish more advanced forms of production, trading and professional organization of doing business overall. Economic cooperatives can be also developed as well as vertical integration of production, processing and trading. Such vertical integration would surely help with linking agriculture with industries and urban economy in general.

In a longer term, agricultural sector requires a comprehensive development strategy, improved production capacities, more efficient processing and more active consumption of products. All of this would help moving this sector towards sustainable development overall and with preparation to face the requirements of international integration processes in particular.

\section{References:}

ADB (2005). Viet Nam: Gender Situation Analysis, Strategy and Program Assessment.

Binh, P.T (2017). Vietnam agricultural development: achievements and constraints, Communist Review, 1.

FAO (2011). Strengthening Capacities to Enhance Coordinated and Integrated Disaster Risk Reduction Actions and Adaptation to Climate Change in Agriculture in the Northern Mountain Regions of Viet Nam, UNJP/VIE/037/UNJ. 
Ian Coxhead and Kim N.B (2010). A Robust Harvest: Strategic Choices forAgricultural and Rural Development in Vietnam. Project 00050557: Support for the Formulation of Vietnam's Socioeconomic Development Strategy (SEDS), 2011-2020.

Khai, L.D et al. (2013). Land Tenure Reform in Asia and Africa: Assessing Impacts on Poverty and Natural Resource Management. Palgrave Macmillan.

Toan, T. D \& Phuong, N. D (2014). A situational analysis of agricultural production and marketing, and natural resources management systems in northwest Vietnam. Research program on Integrated Systems for the Humid Tropics.

Paper submitted

Paper accepted for publishing

Paper published online
04 June 2019

19 August 2019

01 October 2019 